\title{
THE FACTORS OF RELATED TO NURSING JOB SATISFACTION IN THE IN PATIENT AT HARAPAN BUNDA BATAM HOSPITAL 2015
}

\author{
Ns . As ri Sri Rahmadeni,MKep ${ }^{1)}$ \\ STIKes Mitra Bunda Persada \\ Batam email: anias fri@g mail.com
}

\author{
Submitted : 13-02-2020, Reviewer:27-02-2020, Accepted: 27-02-2020
}

\begin{abstract}
Job satisf action is a pleasant mental state perceived by a person on the job because of the requirement for adequately. Someone who has a high level of job satisf action will have a positive feeling about the job. This study aims to look at the $f$ actors associated with job satisf action of nurses in the hospital harapan bunda batam 2015. The design of this study using cross sectional study design. Samples tak en by total sampling with total sample of 74 nurses. Results of the study are the factors mitivato r a nd hygiene factors more than half are not implemented. Statistical test results obtained Motivatorf actors that have a relationship with the achievement of satisf action of nurses are work ing nurse with $p=0.020$, recognitio $n$ of the work with $p=0.003$, and the work itself with $p=0.027$. Hygienef actors linked to the sat $i$ sf action of nurses are working regulations with $p=0.013, p=0.011$ salary, and interpersonal relationships wit $h$ $p=0.070$. Af ter multivariate analysis obtained factor most dominant working conditions and job satisf action of nurses with $O R=5.123$. The implications of this study demonstrated that the mother's hospital hopes more attention to factors related to job satisf action of nurses so that the quality of serv ice provided nurses can work well.
\end{abstract}

Keywords: satisf action, Motivator factors, Hygiene factors

\section{INTRODUCTION}

Job satisfaction is an interesting conversation for hospitals and health workers including nursing. For nurses, job satisfaction will lead to pleasant feelings at work, while for hospitals job satisfaction is useful for increasing production effort, improving attitudes and behavior of nurses (Suwatno \& Priansa, 2011). According to Robbins and Judge (2009) define the job satisfaction as a positive feeling about work as a result of evaluating the work characteristics. While, according to Sondang P Siagian (2011) argues that job satisfaction is a person's perspective both positive and ne gative about his work. Thus nurses who have high job satisfaction will be positive about the ir work, thus increasing the quality of nursing services that they provide to patients and families as well as them. In fact, the hos pitals in Indonesia still have problems in nurse job satisfaction.

Several studies have shown that, there are still many nurses who experience dissatisfaction with their work. According to Suryanto, Sutomo and Setyawati (2011) the level of nurse satisfaction at PKU Muhammadiyah Gombong Hospital is only $76.85 \%$, as well as the results of research by Maryanto, Pujiyanto and Setyono (2013) the level of nurse satisfaction at Demak Private Hos pital was lower than in PKU Muhammadya Gambong Hospital, that is, only $60.5 \%$. Whereas, Tahsania's research (2013) at the Rumah Sehat Terpadu Parung Bogor Hospital also showed a very low rate of nurse satisfaction at only $58.7 \%$. When 
viewed from the three hospitals, it can be concluded that the level of nurse satisfaction is varies and is far be low the customer satisfaction standards set by the Ministry of Health. The absolute of satisfaction level benchmarks do not exist because each individual employee has a different standard of satisfaction. According to Hasibuan (2005) the indicators of job satisfaction are only measured by discipline, work morale, turnover. Operationally, nurses who have high job satisfaction will enjoy their jobs, love the ir jobs, has high morale in work, discipline and achievement. So that, it can improve patient satisfaction both in outpatient and hospitalize d.

Some research on nurse satisfaction in the inpatient room also shows low job satisfaction. Nias and Sartika's (2012) research in the inpatient room at Fatmawati General Hospital in Jakarta reported $73.78 \%$ of nurses' job satisfaction. The number of occupational nurses in Inpatient care at RSUP Prof. Dr.R.D Kandau Manado is only $65.8 \%$. Tanpalang, Tuda and Waraw (2013) also reported that low nurse job satisfaction in Inpatient at Liunkendaga Tahuna Hospital was $61 \%$. Overall, the job satisfaction of nurses, both treated and hos pitalized is still below the standards desired by the Ministry of Health, which is less than $90 \%$. This condition is quite a chore for nursing managers to find the cause of this nurse's low satisfaction.

The theory of job satisfaction is very much expressed by experts, including the theory of difference, justice and the theory of two factors. According to the the ory the difference in one's job satisfaction can be obtained by comparing what is expected with reality, while the the ory of justice people will feel satisfied or not satisfied, depending on whether he feels the existence of justice or not for a situation
(Mangkune gara 2009). The two the ories above are different from the two-factor theory proposed by Frederick Herzberg (2000) where job satisfaction is influenced by motivator factors and hygiene factors.

The factors of motivator are factors that encourage workers to be satisfied with the ir work. According to Gibs on and Sopiah (2008) motivator factors consist of achievement, recognition, work itself, responsibility and development. While, the Hygiene Factor is a source of dissatisfaction consisting of company and administrative regulations, supervision techniques, supervision, salary, interpers onal relations, working conditions, job security, and status. The the ory of two factors explains that job satisfaction is influenced by the driving factors and obstacles to the emergence of employee job satisfaction.

Some of the results of research on factors that influence nurses' job satisfaction report the causes of varying nurse job satisfaction. The results of The and Tucunan's research (2014) show the factors that influence nurse job satisfaction at RSUP Prof. Dr.R.D Kandou Manado is a factor of work security, type of work and supervision of the head of the room. The study was also supported by the results of research conducted by Hidayanto (2002) in Ambarawa Hospital, factors related to nurse job satisfaction were employment status, years of service and incentives. Based on the satisfaction of two factors and the research the ory above, there are twelve (12) factors related to nurse job satisfaction, namely; 1) achie vement 2) recognition, 3) work itself, 4) responsibility, 5) development 6) company regulations, 7) supervision techniques, 8) salary, 9) interpers onal relations, 10) working conditions, 11) job security, and 12) status. Faktor-faktor ini kemungkinan juga mempengaruhi tingkat These factors may also influence the evel of satisfaction of 
nurses at Harapan Bunda Hos pital. Harapan Bunda Batam Hospital is a Type C Private Hos pital, which has 106 nurses (2014), of which 76 nurses / $71.7 \%$ nurses are in the inpatient room consisting of 2,3,4,5 floors and ICU with $9.4 \%$ undergraduate nursing education qualifications, $61.4 \%$ DIII Nursing, $19.8 \%$ DIII Midwifery, 8.5\% SPK and $0.9 \%$ SPRG (2014 The Data of Harapan Bunda Hospital).

Based on the initial survey that the researchers conducted on March 16, 2015 at the Harapan Bunda Hospital about nurses inpatient job satisfaction using questionnaires distributed to 25 nurses as samples, the results showed that nurses' satisfaction at work was only $60 \%$, while the minimum standard of service (SPM ) establish nurse job satisfaction should not be less than $90 \%$ (Kepmenkes RI 129/Menkes/SK/II/2008).

When associated with factors that cause dissatisfaction, data obtained at Harapan Bunda Hospital Batam development/promotion is rarely done even if there are mostly given to certain people only, while nurses also get less recognition/appreciation for the good achievements that have been made so that this can reduce the work motivation of nurses at work.

Based on existing phenomena, the researchers are interested in conducting research on factors related to job satisfaction of nurses in the Inpatient Room of Harapan Bunda Batam Hospital

\section{RESEARCH METHOD}

The type of this research is descriptive analytic research with cross sectional design. In this study the population was all nurses inpatient hospital expectation mothers, namely 74 nurses. Sampling with total sampling.
RESULTS DISCUSSION

Nurse Job Satisfaction in the Inpatient Room of Harapan Bunda Batam Hospital in 2015

Table 5.1 Frequency Distribution of Implementing Nurses in the Inpatient Room of the Harapan Bunda Hospital in

\begin{tabular}{llll}
\hline No & JobSatis faction & F & \% \\
\hline 1 & Satisfied & 31 & 41,9 \\
2 & Not Satisfied & 43 & 58,1 \\
\hline
\end{tabular}

Batam in $2015(n=74)$

Table 5.1 shows the job satisfaction of implementing nurses inpatient care at the Harapan Bunda Hospital in 2015 in 2015, more than half were dissatisfied $(58.1 \%)$.

Factors that Suppo rt Exe cuting Nurse $s$ in the Inpatie nt Room of Harapan $B$ unda Hos pital in $B$ atam in 2015

Table 5.2 Fre que ncy Dis tribution of Exe cuting Nurs e s Hos pitalization $B$ as ed on Motiv ator Factors in B atam Harapan

Harapan Hos pital in $2015(n=74)$

\begin{tabular}{|c|c|c|c|}
\hline & D Motivat or Factors & Categ ory & f $\%$ \\
\hline \multirow[t]{2}{*}{1} & A ch ievement of worl & k A chieved & 2837,8 \\
\hline & & Not achieved & $46 \quad 62,2$ \\
\hline \multirow[t]{2}{*}{2} & Job recognition & Acknowled ged & 2331,1 \\
\hline & & Not recog nized & 5168,9 \\
\hline \multirow[t]{2}{*}{3} & The work its elf & Well & 3344,6 \\
\hline & & Notgood & 4155,4 \\
\hline \multirow[t]{2}{*}{4} & Job res ponsibilities & To be res ponsibe? & $\mathrm{e} 3344,6$ \\
\hline & & Not res ponsible & 4155,4 \\
\hline \multirow[t]{2}{*}{5} & Career developmen $t$ & Exis $\mathrm{t}$ & 2027,0 \\
\hline & & Not exis $\mathrm{t}$ & 5473,0 \\
\hline
\end{tabular}

Table 5.2 shows that more than half $(62.2 \%)$ of nurses implementing hos pitalization did not fulfill the success factor in preparation. Factor Recognition of the work of implementing nurses is no more than half $(68.9 \%)$. The work factor itself the implementing nurse worked well (44.6\%) with not good (55.4\%) almost the same. The factor of responsibility for nurses is almost the same between responsible nurses (44.6\%) and irresponsible nurses (55.4\%). The factors of career development for implementing nurses were mostly (73.0) categories of no development. 
Inhibiting Factors (Hygie ne Facto is) Exe cuting Nurs es in the Inpatie nt Room of Harapan $B$ unda Hos pital in B atam in 2015

Table 5.3 Fre que ncy Dis tribution of Exe cuting Nurses in Inpatie nt Rooms Based on Hygie ne Factors in Batam Harapan B unda Hos pital in $2015(n=74)$ No Motivator Factors Categ ory f \% 1 Work Regulation Corres ponding $34 \quad 45,9$

Not corres ponding $\mathrm{g} 40 \quad 54,1$

2 Supervision Do $32 \quad 43,2$

$\begin{array}{lll}\text { Aren ot done } & 45 & 56,8\end{array}$

3 Salary Corres ponding $36 \quad 48,6$

Not corres ponding $38 \quad 51,4$

4 Interpersonal Well $\quad 26 \quad 35,1$

$\begin{array}{llll}\text { Relations hip } \quad \text { Notgood } & 48 & 64,9\end{array}$

5 W orking Conditions Well $\quad 35 \quad 47,3$

$\begin{array}{llll} & \text { Notgood } & 39 & 52,7\end{array}$

6 Sens e of Security Safe $26 \quad 35,1$

$\begin{array}{lll}\text { Notsafe } & 48 & 64,9\end{array}$

\begin{tabular}{lllll}
7 & Statu s & Acknowledged & 24 & 32,4 \\
\hline
\end{tabular}

\begin{tabular}{lll} 
Not recognized & 50 & 67,6 \\
\hline
\end{tabular}

Table 5.3 shows that the working rules of the nurses implementing the appropriate category $(45.9 \%)$ and inappropriate $(54.1 \%)$ are almost balanced. The factor of supervision of nurses implementing almost the same between existing categories $(43.2 \%)$ and none $(56.8 \%)$. The salary factor for nurse nurses between the appropriate categories $(48.6 \%)$ and inappropriate $(51.4 \%)$ is almost as harge. Factors of interpersonal relations of implementing nurses were more than half with non-good categories of $(64.9 \%)$. Factors of working conditions of nurses implementing good and not good categories are almost balanced. The factor of security is more than half of the implementing nurses working in the insecure category of $(64.9 \%)$. The factor of the status of implementing nurses was more than half of the categories that were not recognized $(67.6 \%)$.

Supporting Factors (Motivator Factors ) With Exe cuting Nurse Job Satis faction Le ve $I$ in Inpatie nt Room of Harapan $B$ unda $B$ atam Hos pital in 2015
Table $\quad 5.4 \quad$ Re lations hip be twe en Motivator Factors and Occupational Nurs e Satis faction Le ve ls in Inpatie nt Rooms of the Harapan $B$ unda Hos pital in B atam in $2015(n=74)$

\begin{tabular}{|c|c|c|c|c|c|c|}
\hline \multirow{3}{*}{$\begin{array}{l}\mathbf{N} \\
\mathbf{0}\end{array}$} & \multirow{3}{*}{ Variable } & \multirow{3}{*}{ Criteria } & \multicolumn{4}{|c|}{ Satis faction } \\
\hline & & & d & Sat & Total & \multirow{2}{*}{ v } \\
\hline & & & $\%$ & & $\%$ & \\
\hline \multirow[t]{2}{*}{1} & Achiev emen & tAchieved & $17 \quad 60,7$ & 11 & $\begin{array}{lll}39,3 & 28 & 10\end{array}$ & 0,020 \\
\hline & of work & Notachieved & 1430,4 & 32 & $69,6 \quad 460$ & \\
\hline \multirow[t]{2}{*}{2} & Job & A ckn owled ged & 1669,6 & 7 & $\begin{array}{lll}30,4 & 23 & 10\end{array}$ & 0,003 \\
\hline & recognition & Not recog nized & 1529,4 & 36 & $70,651 \quad 0$ & \\
\hline \multirow[t]{2}{*}{3} & The worl & kW ell & 1957,6 & 14 & $42,4 \quad 33 \quad 10$ & 0,027 \\
\hline & its elf & Notgood & 1229,3 & 29 & $70,7 \quad 41 \quad 0$ & \\
\hline \multirow[t]{2}{*}{4} & Job & To be res ponsibl & k13 39,4 & 20 & $60,6 \quad 33 \quad 10$ & 0,878 \\
\hline & $\begin{array}{l}\text { res ponsibiliti } \\
\text { es }\end{array}$ & iNot res ponsible & 1843,9 & 23 & $56,1 \quad 41 \quad 0$ & \\
\hline 5 & $\begin{array}{l}\text { Career } \\
\text { development }\end{array}$ & $\begin{array}{l}\text { Exis } t \\
\text { Not exis } t\end{array}$ & $\begin{array}{ll}8 & 40,0 \\
23 & 426\end{array}$ & 12 & $\begin{array}{lll}60,0 & 20 & 10 \\
57 & 54 & 0\end{array}$ & 1,000 \\
\hline
\end{tabular}

Table 5.4 shows the achievement factors of work with the job satisfaction of nurse executives obtained, namely $60.7 \%$ achievement of work achieved said satisfied with his job more than half of the achievement of work was not achieved but said satisfied with his job (39,\%). The Chisquare test results showed $\rho=0.020$ OR 3.5 (95\% CI 1.3-9.5) meaning that there was a relationship between the achievement of the nurse's work performance and job satisfaction. The achievement of work achieved has a chance 3.5 times to be satisfied with the work compared to the achievement of work that is not achieved.

The work recognition factor with the satisfaction of the executing nurse obtained $69.6 \%$ of recognized work acknowledgments saying that more than half of the work acknowledgments were satisfied with the ir work but said they were satisfied with the ir work (29.4\%). The Chi-square test results show $\rho=0.003$ OR 5.5 (95\% CI 1.8-16.4) meaning that there is a relationship between the recognition of nurses' work and job satisfaction. Recognized work recognition has a chance of 5.5 times to be 
satisfied with his job compared to recognition of work that is not recognized.

The work factor itself with satisfaction of implementing nurses was obtained by $57.6 \%$ of the work itself, both said that they were satisfied with the ir work more than half of the jobs that were not good but said they were satisfied with the ir work $(29.3 \%)$. The Chi-square test results show $\rho=0.027$ OR 3.3 (95\% CI 1.3-8.6) meaning that there is a relationship between the nurse's work and job satisfaction. good jobs have a chance 3.3 times to be satisfied with their work

The factors of work responsibility with satisfaction of nurse nurses obtained $39.4 \%$ good work responsibilities said that being satisfied with his job was almost the same as being irresponsible but said that he was satisfied with his work (43.9\%). Chi-square test results show $\rho=0.878$ OR 0.8 (95\% CI 0.3-2.1) meaning that there is no relationship between work responsibility and job satisfaction of the executive nurse.

Career development factors with satisfaction of executive nurses obtained $40.0 \%$ of career development was done saying said that being satisfied with his job was almost the same as those with no career development but said he was satisfied with his work $(42.6 \%)$. Chi-square test results show $\rho=1,000$ OR 0.9 (95\% CI $0.3-2,6)$ meaning that there is no relationship between career development and job satisfaction of executive nurses.

Multiv ariate Analys is

Table 5.6 B iv ariate Analys is of Motivat o r and Hygie ne Factors with Job Satis faction for Nurse s Imple me nting Inpatie nt Care at the Harapan B unda Hos pital in B atam in $2015(n=74)$

\begin{tabular}{lll}
\hline No & Variable & P value \\
1 & Achievement & 0,020 \\
2 & Recognition & 0,003 \\
3 & Job & 0,027 \\
4 & Regulation & 0,013 \\
\hline
\end{tabular}

\begin{tabular}{lll}
\hline 5 & Salary & 0,011 \\
6 & Interpersonal Relationship & 0,023 \\
7 & Working conditions & 0,070 \\
8 & Sense of security & 0,198 \\
\hline
\end{tabular}

Table 5.6 shows the independent variables included in multivariate modeling which show $\mathrm{p}$ value $<0.25$

Table 5.7 Res ults of Logis tic Regression Analys is The Re lations hip of Achie ve me nt, Re cognition, Employme nt, Regulation, Salary, Inte rpe rs ona Re lations hip, Working Conditions and Se nse of security with Occupational

\section{Harapan B unda B atam Hos pital in 2015} $(\mathrm{n}=74)$

\begin{tabular}{|c|c|c|c|c|c|}
\hline \multirow[t]{2}{*}{ No } & \multirow{2}{*}{ Variable } & \multirow{2}{*}{ Sig. } & \multirow[t]{2}{*}{ OR } & \multicolumn{2}{|c|}{$95,0 \%$ C.I } \\
\hline & & & & Lower & Upper \\
\hline 1 & A chievement & 208 & 2,305 & ,629 & 8,451 \\
\hline 2 & Recog nition &, 040 & 4,433 & 1,070 & 18,365 \\
\hline 3 & Job &, 514 & 1,521 & ,432 & 5,363 \\
\hline 4 & Regulation & ,119 & 2,624 &, 779 & 8,834 \\
\hline 5 & Salary & ,088 & 3,025 & ,847 & 10,803 \\
\hline 6 & $\begin{array}{l}\text { In terpers onal } \\
\text { Relations hip }\end{array}$ &, 545 & 1,517 & ,393 & 5,853 \\
\hline 7 & $\begin{array}{l}\text { W orking } \\
\text { conditions }\end{array}$ & ,012 & 5,123 & 1,426 & 18,406 \\
\hline 8 & $\begin{array}{l}\text { Sense } \\
\text { security }\end{array}$ of & ,689 & 1,315 & ,3444 & 5,020 \\
\hline & Constant &, 000 &, 000 & & \\
\hline
\end{tabular}

Table 5.7 shows that the results of the multivariate analys is performed on the independent variables are obtained variables that have a value of $p<0.05$ then,

The most dominant variable working conditions affect the job satisfaction of inpatient nurses in Harapan Bunda Batam Hospital. The conclusion is that nurses who say good working conditions have the opportunity to improve nurse job satisfaction better 5.1 times compared to nurses who say the working conditions are not good at the Harapan Bunda Batam Hospital in 2015.

Dis cus s ion

Exe cuting Nurs e Job Satis faction in the Inpatie nt Room of Harapan B unda Hos pital in B atam in 2015 
The results showed that the job satisfaction of nurses inpatient care for the Harapan Harapan Hos pital in Batam in 2015 was more than half $(51.8 \%)$ were not satisfied.

Job satisfaction is influenced by many factors so that job satisfaction can represent the attitude as a whole from a particular part of work, if someone has very high satisfaction one day the person can still feel dissatisfied with one or several factors that influence job satisfaction.

The Mos t Influe ntial Working Conditions Agains $t$ Nurse Job Satis faction in the Inpatie nt Room of Harapan $B$ unda Hos pital in $B$ atam

The results of multivariate analys is conducted on six variables of achievement, recognition, work itself, work rules, salary, interpersonal relations, work conditions and security, all six variables were taken from the $\mathrm{p}$ value $<0.25$. The multivariate analys is performed was found that the most influential on the job satisfaction of nurses implementing hospital hospitalization, the expectation of mothers was the factor of working conditions. The final statistical test results have an OR value (expB) of 5.123, meaning that the strength of the good working condition variable relationship has

5.1 times to make nurses satisfied with the ir work compared to poor working conditions.

Working conditions as a series of conditions or circumstances of the work environment of a company that is the place of work of employees who work in that environment. Good working conditions that are comfortable and support workers to be able to carry out their activities well include everything in the employee's environment that can affect performance, as well as work safety and security. Therefore, working conditions which consist of factors such as physical conditions, psychological conditions, and temporary conditions of the work environment, must be considered so that workers can feel comfortable in the ir work so that they can improve work productivity both personally and organizationa lly.

Management of an organization must pay attention to the environmental conditions in which its employees work to provide comfort. Hospital management must have its own plans for how to manage and prepare a safe and comfortable environment for employees to work, so that any planned work can run smoothly and properly.

Sedarmayanti (2001) states that broadly speaking, the type of work environment is divided into 2 namely: (a) physical work environment, and (b) non-physical work environment. The physical work environment includes: lighting, air temperature, humidity, a ir circulation, noise, mechanical steering, odor, color management, decoration, music and security in the workplace. While, the non-physical work environment includes social relations in the workplace either between superiors and subordinates or relationships between subordinates.

The research conducted found that there were still many working conditions that said were not satisfied, this was because the place of work was working from a nonphysical environment of the hospital which was less comfortable because of its location close to the highway so that it was noisy with vehicles but not too influential in provide nursing care.

The problems that occur in the hos pital hope that the mother can be concluded that the implementation of the management function is not optimal, so that many conflicts occur between fellow nurses and other staff that cause less cooperation is well established. Therefore, the hospital hopes mothers must improve management functions, especially the control system so that there are people who are aware of every event that is able to find solutions effectively and efficiently 
with the parties involved. The existence of a good control system will be able to improve the quality of nursing services, because in working if the physical and non-physical environment is good, it will make nurses work safely and comfortably and have the ir own satisfaction.

\section{CONCLUSION}

1) Nurses' satisfaction in hos pitalization for Harapan Bunda Hospital in 2015 was found more than half of the nurses were dissatisfied.

2) The supporting factors (Motivator Factors) of nurses implementing Inpatient Harapan Bunda Hospital in 2015 were obtained: more than half of the achievements of the nurse pelaksan work were not achieved, more than half of the recognition of the nurses implementing the nurses, the work itself was more than half not good, the achievement of the work of implementing nurses is largely not achieved, the work responsibilities of implementing nurses are more than half irresponsible and more than half of the development of nurses' work is not done.

3) Hygiene factors for inpatient nurses in Harapan Bunda Hospital in 2015 were obtained: more than half of the work rules for implementing nurses were inappropriate, more than half of the supervision of implementing nurses was done, more than half of the salary for implementing nurses was inappropriate, more than half of the nurses 'interpersonal relationships were not good, more than half of the nurses' working conditions were not good, the security of more than half of the nurses was not safe, more than half of the status of the nurses implementing the $m$ was not recognized.
4) Supporting factors (Motivator Factor) that have a relationship with satisfaction of inpatient nurses implementing the Harapan Bunda Hospital in Batam in 2015 are the achievement of nurse work, recognition of work, and the work itself.

5) Inhibiting factors (hygiene factors) that have a relationship with satisfaction of nurses implementing Inpatient Harapan Bunda Batam Hospital in 2015 are work regulations, salary, and interpersonal relations.

6) The determinant factors that influence the job satisfaction of the executive nurses at the Harapan Bunda Hospital in Batam in 2015 are working conditions with a value of OR 5.123.

\section{REFERENCES}

Anwar Prabu Mangkunegara, 2005.Evaluasi Kinerja SDM. Bandung : Refika Aditama

Gatot,D.B $\&$

Wiku,Adisas mito.(2005).Hubungan

Karakteristik Perawat, Isi Pek erjaan dan Lingkungan Pek erjaan Terhadap Kepuasan Kerja Perawat di Instalasi Rawat In ap RSUD Gunung Jati.Cirebon Handoko,T.(2001).Manajemen Personalia dan Sumber Daya Manusia. Yogyakarta. Penerbit BPFE. Yogyakarta.

Hasibuan,MSP.(2001).Manajemen Sumber Daya Manusia. Cetakan Keempat. Jakarta:Bumi Aksara. . (2003). Manajemen Suimber Daya Manusia, Dasar-dasar Kunci Keberhasilan. Jakarta:Djamberta (2008). Manajemen Sumber Daya Manusia. Edisi Revisi. PT Bumi Aksara. Jakarta.

Herzberg F. 2000. Frederick Herzberg's Motivation And Hygiene Factors. Luthans,F.(2006). Perilak $u$ organisasi.Yogyakarta.Penerbit Andi. 
Mangkune gara, Anwar Prabu. 2004. Manajemen Sumber Daya Manusia Perusahaan.Bandung. PT Remaja Rosdakarya.

(2005).Manajemen Sumberdaya Manusia Perusahaan. Cetak an Keenam. Bandung.

Maryanto,Pijiyanto Tri Ismu \& Setyono,Singgih.(2013).Hubungan Gaya Kepemimpinan Kepela Ruangan dengan Kepuasan Kerja Perawat di Rumah Sakit Swasta Demak.Semarang.

Munandar, A.S.(2008).Psik ologi Industry dan Organisasi.Jakarta:Penerbit Universitas Indonesia (UI-Press).

Noras, Jamila Upik \& Sartika,Ratu Ayu Dewi(2012).Perbandingan Tingk at Kepuasan Perawat Dan Pasien .Jurnal Kesmas Jakarta.

Rivai, Veitzhal. (2004). Manajemen Sumber Daya Manusia Untuk Perusahaan. Jakarta: Murai Kencana.

Robbins,Stephen P \& Jedge T.A.(2009).Perilak $u$ Organisasi.Jakarta. . (2006). Perilaku Organisasi, Edisi10.Jakarta: PT. Index

Sedarmayanti(2000).Sumber Daya Manusia dan Produktifitas Kerja.Bandung Mandor Mayo.

Siagian.(2002).Kiat Meningkatkan Produktivitas Kerja.Jakarta:Rineka Cipta. (2008). Manajemen Sumber Daya Manusia.Jakarta:Bumi Aksara.

Suwatno,H \& Priansa,D.J.(2011).

Manajemen Sumber Daya Manusia dalam Organisasi Publik dan Bisn is.Alfabeta:Bandung.

Swansburg, R.C \& Swansburg, R.J.(1999).Introductory Management And Leadership For Nurses.Canada Jones and Barlet Publishers.

Tahsinia, Nadia. (2013). Faktor-Faktor Yang Berhubungan Dengan Kerja
Perawat di Rs Rumah Sehat Terpadu Parung Bogor.

Tampilang,et al(2013).Hubungan Supervise Kepala Ruangan dengan Kepuasan Perawat Pelaksana di RSUD Liunkendage Tahuna Uneversitas Samratulangi Manado.Jurnae-NERS.

The, Feniet al(2013). Analisa FactorFaktor Yang Berhubungan Dengan Kepuasan Kerja Perawat Di In stalasi Rawat Inap A BLU RSUP Prof Dr.R.D.Kandou Manado. Wibowo.(2007).Manajemen Kinerja Edisi Ke Dua PT.Raja Grafindo persada Liberty. Yogyakarta.Andi Offiset.Yogyakart 